\title{
Preliminary Proximate Composition and Mineral contents of Five Edible Insects from Cameroon
}

\author{
Achu Mercy B. Loh ${ }^{1}$, K.B. Yisa Njowe $e^{1,2}$ and M.M. Kana Sop ${ }^{3 *}$ \\ ${ }^{1}$ Department of Biochemistry, Faculty of Science, P.O. Box 812, \\ University of Yaoundé I, Cameroon \\ ${ }^{2}$ Centre for Food and Nutrition Research, Institute of Medical Research and Medicinal \\ Plant Studies, Ministry of Scientific Research and Innovation, Yaoundé, Cameroon \\ ${ }^{3}$ Department of Biochemistry, Faculty of Science, P.O. Box 24157 , \\ University of Douala, Cameroon \\ *Corresponding author:
}

\section{A B S T R A C T}

\section{Keywords}

Protein calorie malnutrition, Edible insects, Macronutrients, Minerals Cameroon.

Article Info

Accepted: 20 February 2017 Available Online: 10 March 2017
This study deals with the analysis of the nutritive value of five edible insects of the orders, Lepidoptera (caterpillars) and Coleoptera (raphia palm weevil) from North West and Centre regions in Cameroon. The contents in water, ash, lipids, proteins and crude fibres were determined according to standard AOAC methods, minerals by Flame Atomic Absorption Spectrophotometry and phosphorus by colorimetry. The water content ranged from 26 (R. phoenicis) to $72.35 \%$ fresh weight (I. dione). The lipid content was from 6.59 (I. oyemensis) to $41.36 \%$ (R. phoenicis), proteins from 10.87 (I. dione) to16.72\% ( $R$. phoenicis), ash from 0.66 (I. dione) to $1.29 \%$ (R. phoenicis), crude fibres from 2.10 (I. dione) to $5.60 \%$ (R. phoenicis) and total carbohydrates from 5.16 (I. truncata) to $8.54 \%$ edible portion (EP) (R. phoenicis). The results showed that these insects were good sources of macronutrients, especially $R$. Phoenicis, whose protein and lipid levels make up more than $50 \%$ of the weight, making them good sources for the fight against protein-calorie malnutrition. The mineral contents (expressed in $\mathrm{mg} / 100 \mathrm{~g} \mathrm{EP}$ ) were as follows: Phosphorus was from 69.91 (I. oyemensis) to180.43 (R. phoenicis), calcium from 20.26 (I. dione) to 37.84 (R. phoenicis), magnesium from 32.13 (I. dione) to103.44 (R. phoenicis), potassium from 152.31 (I. dione) to 296.01 (R.phoenicis), sodium from 0.38 (I. oyemensis) to 1.68 ( $R$. phoenicis), copper from 0.26 (I.truncata) to1.57 ( $R$. phoenicis), manganese from 0.50 (B. alcinoe) to 8.32 (Imbrasia dione), iron from 1.12 (I. dione) to 7.47 ( $R$. phoenicis) and zinc from 2.24 (I. truncata) to 6.23 ( $R$. phoenicis). The Coleoptera $(R$. Phoenicis) also had the highest level of all the minerals analysed except $\mathrm{Mn}$, and could therefore be used to help against some mineral deficiencies. The $\mathrm{Ca} / \mathrm{P}$ ratios were $<0.5$, implying enhanced $\mathrm{Ca}$ absorption in the gut.

\section{Introduction}

Insects are Non Wood Forest Products (NWFP) that are collected from the forest. In Cameroon, they are mostly collected by women and children during their season of abundance for food or sold to fetch cash. In the South West region of Cameroon, most households practicing the gathering and trading of beetles fetch 100000 to 200 
000XAF annually per household while a few, about $5.2 \%$ earn up to 800000 XAF annually (Muafor et al., 2012). To the forest people of the East region of Cameroon, some edible insects especially beetles are believed to make children walk early and in adult males, it is believed to increase sexual resistance. In the past, cooked palm weevil larvae was offered as special dishes during important ceremonies and top restaurants in Urban cities. Augosoma larvae was to be eaten only by initiated persons in some villages in the East region (Muafor et al., 2014; Muafor et al., 2015).

In Cameroon the prices of meat and fish fluctuate with frequent price hikes. Low income Cameroonians strain to put three balanced meals per day on the table and in the long run, develop malnutrition related diseases (Pongou et al., 2006). Insects are an essential source of quality proteins compared to fish and meat (Durst and Shono, 2010) and can meet up with the protein needs of the carbohydrate rich staple foods of low income earners, especially children. The World Health Organisation showed that $33 \%$ of children aged 5 years and below suffer from malnutrition in Cameroon and should edible insects from Cameroon prove to be a good source of proteins, vitamins and minerals, then malnutrition could be greatly reduced in the future. In addition to its consumption, low income earners can make a living out of farming and trading edible insects (WHO, 2012).

Most nutrition research on edible insects from Cameroon has been on the lipid profile of palm weevil larvae and crickets, the effects of processing techniques on the functional properties of palm weevil larvae in the West and Centre regions (Womeni et al., 2009; Womeni et al., 2012), insect trade in the South West region (Munford et al., 2012), the consumption of Augosoma larvae in the East region and an inventory carried out on short horn grasshoppers in the West Region (Muafor et al., 2014). Very little work has been done on the nutritive value of edible insects from Cameroon, hence the need for available analytical data of these insects.

The aim of this study is therefore to determine the proximate composition (water, lipid, protein, ash, crude fibre and carbohydrate contents) and mineral ( $\mathrm{Ca}, \mathrm{P}, \mathrm{Mg}, \mathrm{K}, \mathrm{Na}, \mathrm{Cu}$, $\mathrm{Fe}, \mathrm{Mn}$ and $\mathrm{Zn}$ ) contents of 5 species of edible insects (of the orders Lepidoptera and Coleoptera) from Cameroon. The insects were Imbrasia oyemensis, Imbrasia truncata, Imbrasia dione, Bunaea alcinoe and Rhynchophorus phoenicis. These five species were chosen because they were abundant during the period of harvest and are among the most widely consumed insects in these regions.

\section{Materials and Methods}

\section{Collection and treatment of samples}

Five species of edible insects were collected from the North West and Centre Regions of Cameroon. They were collected life from their host plants during their periods of abundance (from August to November 2014). About 300g were collected for each specie and transported to the laboratory in perforated plastic containers (Table 1).

The insect samples were killed by freezing at $0^{\circ} \mathrm{C}$ for 24 hours. The frozen samples were then allowed to thaw at room temperature, the inedible portions were removed and the edible portions dried in an air-ventilated oven (Memmert) at $50^{\circ} \mathrm{C}$ for $72 \mathrm{hrs}$. The dried samples were ground into powder using an iron hand-grinding machine (Victoria) and stored in air-tight bottles for further analysis. The analyses of the samples were done in triplicate. 


\section{Methods of analyses}

\section{Proximate composition}

The macronutrient contents were analysed in triplicate while the micronutrients were analysed in duplicate. The moisture content was determined by drying the fresh samples in an oven at $100-105^{\circ} \mathrm{C}$ to constant weight. Total lipids were determined by continuous extraction in a Soxhlet apparatus for $8 \mathrm{~h}$ using hexane as solvent. The crude protein contents were evaluated through nitrogen determination by the Kjeldahl method and conversion to proteins by multiplying the quantity of nitrogen by the coefficient 6.25. Ash contents were determined by incineration in a furnace at $550^{\circ} \mathrm{C}$, crude fibres by sequential hot digestion of the defatted sample with dilute acid and alkaline solutions and total carbohydrates by difference (AOAC, 1980).

\section{Determination of mineral content}

The mineral contents $(\mathrm{Ca}, \mathrm{Mg}, \mathrm{K}, \mathrm{Na}, \mathrm{Cu}, \mathrm{Fe}$, $\mathrm{Mn}$ and $\mathrm{Zn}$ ) were determined using an Atomic Absorption Spectrophotometer (BUCK Scientific 205)? as described by Benton and Vernon (1990), while the phosphorus content was analysed using the colorimetric method described by Murphy and Riley (1962).

\section{Preparation of standard stock solutions}

For calcium (Ca), magnesium ( $\mathrm{Mg})$, potassium $(\mathrm{K})$ and sodium $(\mathrm{Na})$ : A solution of $10,000 \mathrm{ppm} \mathrm{K}$ was prepared by dissolving $1.907 \mathrm{~g}$ of $\mathrm{KCl}$ dried in an oven. Into a volumetric flask of $100 \mathrm{ml}, 5 \mathrm{ml}$ of $1000 \mathrm{ppm}$ $\mathrm{K}, 25 \mathrm{ml}$ of $1000 \mathrm{ppm} \mathrm{Ca}, 5 \mathrm{ml}$ of $1000 \mathrm{ppm}$ $\mathrm{Mg}$ and $5 \mathrm{ml}$ of 10,000 ppm Na were put, and the volume completed to the mark with Strontium chloride solution $(5.75 \mathrm{~g}$ of $\mathrm{SrCl}_{2} \cdot 6 \mathrm{H}_{2} \mathrm{O}$ dissolved in deionized water and made to $2 \mathrm{~L}$ with this water).
For copper $(\mathrm{Cu})$, iron $(\mathrm{Fe})$, zinc $(\mathrm{Zn})$ and manganese (Mn): $1 \mathrm{ml}$ of $1000 \mathrm{ppm} \mathrm{Cu}, 8 \mathrm{ml}$ of $1000 \mathrm{ppm} \mathrm{Fe,} 2 \mathrm{ml}$ of $1000 \mathrm{ppm} \mathrm{Zn,} 8 \mathrm{ml}$ of $1000 \mathrm{ppm} \mathrm{Mn}$ were put into a $100 \mathrm{ml}$ volumetric flask, and the volume was completed to the mark with aqua regia solution $(400 \mathrm{~mL}$ of concentrated $\mathrm{HCl}$ and $133 \mathrm{~mL}$ of $\mathrm{HNO}_{3} 70 \%$ dissolved in deionized water and made to $2 \mathrm{~L}$ with this water).

The phosphorus standard solution (1000 ppm) was prepared by dissolving $4.39 \mathrm{~g}$ of $\mathrm{KH}_{2} \mathrm{PO}_{4}$ in $1 \mathrm{~L}$ of deionized water. Using a diluter, volumes of $0,1.25,2.5,3.75$ and $5 \mathrm{~mL}$ of this $\mathrm{KH}_{2} \mathrm{PO}_{4}$ solution were introduced into five 50 $\mathrm{mL}$ propylene tubes, numbered 1 to 5 respectively. The volume in each tube was completed to $50 \mathrm{~mL}$ with the aqua regia solution. This was used for the preparation of the standard curve.

\section{Preparation of standard working solutions}

For calcium (Ca), magnesium (Mg), potassium $(\mathrm{K})$ and sodium $(\mathrm{Na}): 0.5 \mathrm{~mL}$ of aqua regia solution and $19.5 \mathrm{~mL}$ of strontium chloride solution were put into $25 \mathrm{~mL}$ tubes numbered 1 to 5 and homogenized. Volumes of $0,0.25,0.50,0.75$ and $1 \mathrm{~mL}$ of solution were removed from these tubes respectively and replaced by these same quantities of the stock solution and the mixture was vigorously stirred using IKA vortex (Genius 3)

For copper, iron, manganese and zinc: $10 \mathrm{~mL}$ of deionized water and $30 \mathrm{~mL}$ of aqua regia solution were put into $50 \mathrm{~mL}$ tubes numbered 1 to 5 and stirred. Volumes of $0,0.5,1,1.5$ and $2 \mathrm{~mL}$ of solution were removed from these tubes respectively and replaced by these same quantities of the standard solution and the mixture was stirred. These solutions were used for the determination of the standard curves.

For phosphorus, the slightly yellow standard solution was obtained by dissolving $1.056 \mathrm{~g}$ 
of ascorbic acid in 1 litre of deionized water containing $200 \mathrm{ml}$ of Murphy - Riley stock solution (12 $\mathrm{g}$ of ammonium molybdate dissolved in $250 \mathrm{ml}$ of deionized water and $0.291 \mathrm{~g}$ of tartaric potassium antimony dissolved in $100 \mathrm{ml}$ of deionized water. Both solutions were put in a $2 \mathrm{~L}$ volumetric flask containing $140 \mathrm{ml}$ of concentrated $\mathrm{H}_{2} \mathrm{SO}_{4}$ in 1 $\mathrm{L}$ of deionized water and the volume was completed to $2 \mathrm{~L}$ ).

Two porcelain capsules were washed, rinsed with $10 \%$ nitric acid, dried in an oven for 30 min and in a furnace at $500^{\circ} \mathrm{C}$ for 3 hours. 0.5 $\mathrm{g}$ of defatted dry sample was placed in one capsule while the other empty capsule was used as a blank. Capsules were placed in the oven at $500^{\circ} \mathrm{C}$ for 24 hours and then cooled in a desiccator. The residue obtained was whitish (ash). The capsules were rinsed with $15 \mathrm{~mL}$ of aqua regia solution into $50 \mathrm{~mL}$ propylene tubes, stirred for 10minutes and centrifuged at $3000 \mathrm{rpm}$ for 10 minutes. The supernatant of each sample was collected for assays.

For the determination of $\mathrm{Ca}, \mathrm{Mg}, \mathrm{K}$ and $\mathrm{Na}$, $0.5 \mathrm{~mL}$ of the supernatant was diluted in 19.5 $\mathrm{mL}$ strontium chloride solution, while for the determination of trace elements $(\mathrm{Cu}, \mathrm{Fe}, \mathrm{Mn}$, $\mathrm{Zn}), 10 \mathrm{ml}$ of undiluted supernatant were used. Two tubes containing the same quantities of reagents as all the other tubes and deionized water was added for each series of dosage. Standards, samples and blanks were taken to the flame atomic absorption spectrophotometer. The calibration curve of each standard solution was used to determine the concentration (mg/100g DW) of each mineral by extrapolating the absorbance on the corresponding curves.

For phosphorus assay, $0.25 \mathrm{~mL}$ of each sample solution was introduced into $25 \mathrm{~mL}$ tubes and diluted with $19.75 \mathrm{~mL}$ of the working solution. The colour of the solutions of all the tubes (samples, standards and blanks) were allowed to develop for $30 \mathrm{~min}$ and the absorbance was read at $860 \mathrm{~nm}$ against the blank using a spectrophotometer (GENESYS 10S UV-Vis). The phosphorus content of each sample was obtained by extrapolating its absorbance on the calibration curve.

\section{Results and Discussion}

\section{Proximate composition}

The proximate composition of the samples are presented on Table 2. The water content was expressed in $\mathrm{g} / 100 \mathrm{~g}$ fresh weight while the rest of the nutrients are expressed in $\mathrm{g} / 100 \mathrm{~g}$ edible portion (EP).

The water content of the fresh insect samples ranged from $26.72 \%$ (R. phoenicis) to $72.35 \%$ fresh weight (I. dione) with most of them having water contents greater than $65 \%$.

The lipid contents ranged from 6.59 (I. oyemensis) to $41.36 \%$ edible portion ( $R$. phoenicis). The Lepidoptera contained less than $10 \%$ lipids $(6.59-9.29 \%$ EP) while that of Coleoptera was $41 \%$.

The protein contents of the larvae varied from $10.87 \%$ (I. dione $)$ to $16.72 \%$ EP $(R$. phoenicis). The Coleoptera had a higher protein level $(16.72 \%$ EP) than the Lepidoptera, which had less than $15 \%$ protein.

The lowest amount of ash was found in $I$. dione $(0.66 \%)$ and the highest in $R$. phoenicis $(1.29 \% \mathrm{EP})$. This gives an indication of the mineral levels of the insects. The crude fibre contents were between 2.10 (I. dione) and $5.60 \%$ EP (R. phoenicis). The Lepidoptera had crude fibre levels of less than $4 \% \mathrm{EP}$, while $R$. phoenicis had a level of $5.60 \% \mathrm{EP}$. 
The carbohydrate contents varied from 5.16 (I.truncata) to $8.54 \%$ EP (R. Phoenicis). The Lepidoptera had carbohydrate levels of less than $7 \%$ EP while $R$. phoenicis had a level of $8.54 \%$.

On the whole, the Coleoptera (R. Phoenicis) had higher levels of all the macronutrients (lipids, proteins, ash, crude fibre, carbohydrates) than the Lepidoptera.

\section{Mineral contents}

\section{Macrominerals}

The macromineral contents (calcium, potassium, magnesium, sodium and phosphorus) are found on Table 3 . The values were expressed in $\mathrm{mg} / 100 \mathrm{~g}$ of edible portion. From the macrominerals analysed, potassium was the most abundant and sodium the least.

The calcium contents in the analysed edible insects were between 20.26 (I. dione) and $37.84 \mathrm{mg} / 100 \mathrm{~g}$ EP (R. phoenicis). The Lepidoptera had lower calcium content (< $28 \mathrm{mg}$ ) than the Coleoptera (37.84mg).

The phosphorus content was lowest in $I$. oyemensis $(69.91 \mathrm{mg} / 100 \mathrm{~g} \mathrm{EP})$ and highest in R. phoenicis (180.43mg/100g EP). Except for B. alcinoe $(103.97 \mathrm{mg})$, the Lepidoptera had < 90mg of $\mathrm{P}$, while its level in the Coleoptera (180.43mg) was at least twice that found in the Lepidoptera.

The potassium content of the insect samples varied from 152.31 (I. dione) to $296.01 \mathrm{mg} / 100 \mathrm{EP}$ (R. phoenicis). Apart from $B$. alcinoe $(235.43 \mathrm{mg})$, the $\mathrm{K}$ levels of the Lepidoptera were less than $200 \mathrm{mg} / 100 \mathrm{~g}$ EP, while that of the Coleoptera was $296.01 \mathrm{mg}$. The lowest content of magnesium $(32.13 \mathrm{mg}$ ) was found in $I$. dione and the highest in $R$. phoenicis (103.44 mg/100g EP). The Lepidoptera had $\mathrm{Mg}$ levels of less than
$51 \mathrm{mg} / 100 \mathrm{~g}$ EP while its level in the Coleoptera (103.44mg) was at least twice that found in the Lepidoptera.

The sodium levels varied from 0.38 ( $I$. oyemensis) to $1.68 \mathrm{mg} / 100 \mathrm{~g} \mathrm{EP} \mathrm{(R.} \mathrm{phoenicis).}$ The Lepidoptera had less than $0.6 \mathrm{mg}$ sodium, while its level in the Coleoptera $(1.68 \mathrm{mg}$ ) was at least twice the amount found in the Lepidoptera.

On the whole the Coleoptera ( $R$. Phoenicis) had the highest levels of all the macrominerals studied $(\mathrm{Ca}, \mathrm{P}, \mathrm{Mg}, \mathrm{K}$, and $\mathrm{Na})$ than the Lepidoptera. The $\mathrm{Mg}, \mathrm{Na}$ contents of the Coleoptera were at least twice that found in the Lepidoptera.

\section{Microminerals}

The oligoelements analysed (copper, iron, zinc and manganese) are presented on Table 4 below. The values were expressed in $\mathrm{mg} / 100 \mathrm{~g}$ of edible portion. The insect samples were rich in oligoelements with zinc being the most abundant and copper the least.

The copper contents varied from 0.26 (I. truncata) to $1.57 \mathrm{mg}$ ( $R$. phoenicis). The Coleoptera $(1.57 \mathrm{mg} / 100 \mathrm{~g}$ EP) was 5 times richer in copper than the Lepidoptera which had a mean Cu level of $0.31 \mathrm{mg} / 100 \mathrm{~g}$ EP.

The manganese contents of the insect samples varied from 0.50 (B. alcinoe) to $8.32 \mathrm{mg} / 100 \mathrm{~g}$ EP (I. dione). This value in $I$. dione was at least 4 times higher than those of the other species.

The iron content in the insect samples varied from 1.12 (I. dione) to $7.47 \mathrm{mg} / 100 \mathrm{~g} \mathrm{EP}(R$. phoenicis). This value in the Coleoptera $(R$. phoenicis) is about 2 to 3 times higher than those of the Lepidoptera.

The zinc contents ranged from 2.24 ( $I$. truncata) to 6.23 ( $R$. phoenicis). The $\mathrm{Zn}$ 
values of the Lepidoptera were less than $3 \mathrm{mg}$, except for I. dione which had $4.55 \mathrm{mg}$ of $\mathrm{Zn} / 100 \mathrm{~g}$ EP, while that of the Coloeptera was $6.23 \mathrm{mg} / 100 \mathrm{~g}$ EP.

On the whole, the Coleoptera (R. Phoenicis) had the highest levels of all the microminerals studied $(\mathrm{Cu}, \mathrm{Fe}$ and $\mathrm{Zn})$ than the Lepidoptera, except Mn which was much higher in $I$. dione. The $\mathrm{Cu}, \mathrm{Fe}$ and $\mathrm{Zn}$ contents of the Coleoptera were at least twice that found in the Lepidoptera.

Table.1 Orders, Names and regions of collection of samples

\begin{tabular}{|c|c|c|c|c|c|}
\hline $\begin{array}{l}\text { Insect } \\
\text { Order }\end{array}$ & Scientific name & English Name & $\begin{array}{l}\text { Local } \\
\text { Name }\end{array}$ & Tribe & $\begin{array}{l}\text { Region of } \\
\text { Collection }\end{array}$ \\
\hline Lepidoptera & Imbrasia oyemensis & Caterpillar & nsie & Ewondo & Centre \\
\hline Lepidoptera & Imbrasia truncata & Caterpillar & megwamba & Ewondo & Centre \\
\hline Lepidoptera & Imbrasia dione & Caterpillar & nsumu & Lul & $\begin{array}{l}\text { North } \\
\text { West }\end{array}$ \\
\hline Lepidoptera & Bunaea alcinoe & Caterpillar & begombo & Yengono & Centre \\
\hline Coleoptera & $\begin{array}{l}\text { Rhynchophorus } \\
\text { phoenicis }\end{array}$ & $\begin{array}{l}\text { Raphia palm } \\
\text { weevil }\end{array}$ & Nsur & Libum & $\begin{array}{l}\text { North } \\
\text { West }\end{array}$ \\
\hline
\end{tabular}

Table.2 Water, lipid, protein, ash, crude fibre and carbohydrate contents of insects

\begin{tabular}{llccccc}
\hline \hline Samples & \multicolumn{7}{c}{ Macronutrient contents (g/100g EP) } & & & \\
\hline $\begin{array}{l}\text { Scientific } \\
\text { name }\end{array}$ & Water & Lipid & Protein & Ash & Crude fibre $\begin{array}{l}\text { Carbohy } \\
\text { drate }\end{array}$ \\
\hline I. oyemensis & 69.29 & 6.59 & 12.78 & 0.72 & 3.93 & $6.71^{\mathrm{c}}$ \\
I. truncata & 68.59 & 7.20 & 14.71 & 0.75 & 3.61 & 5.16 \\
I. dione & 72.35 & 7.46 & 10.87 & 0.66 & 2.10 & 6.63 \\
B. alcinoe & 65.17 & 9.29 & 14.47 & 0.95 & 3.31 & 6.71 \\
R. phoenicis & 26.72 & 41.36 & 16.72 & 1.29 & 5.60 & 8.54 \\
\hline \hline
\end{tabular}


Table.3 Calcium, potassium, magnesium, sodium and phosphorus contents of insects

\begin{tabular}{llllll}
\hline \hline Sample & \multicolumn{5}{l}{ Macromineral content (mg/100g edible portion) } \\
\hline Scientific name & Ca & K & Mg & Na & P \\
\hline Imbrasia & 27.96 & 167.01 & 49.40 & 0.38 & 69.91 \\
oyemensis & 20.62 & 177.79 & 34.43 & 0.42 & 84.26 \\
Imbrasia truncata & 152.31 & 32.13 & 0.45 & 88.81 \\
Imbrasia dione & 20.26 & 235.43 & 50.43 & 0.54 & 103.97 \\
Bunaea alcinoe & 25.98 & 296.01 & 103.44 & 1.68 & 180.43 \\
$\begin{array}{l}\text { Rhynchophorus } \\
\text { phoenicis }\end{array}$ & 37.84 & & & & \\
\hline \hline
\end{tabular}

Table.4 Micromineral contents of insects

\begin{tabular}{|c|c|c|c|c|}
\hline Sample & Micron & al content (1 & & \\
\hline Scientific name & $\mathbf{C u}$ & Mn & $\mathbf{F e}$ & $\mathbf{Z n}$ \\
\hline Imbrasia oyemensis & 0.32 & 1.66 & 3.36 & 2.62 \\
\hline Imbrasia truncata & 0.26 & 0.76 & 1.14 & 2.24 \\
\hline Imbrasia dione & 0.35 & 8.32 & 1.12 & 4.55 \\
\hline Bunaea alcinoe & 0.31 & 0.50 & 3.75 & 2.91 \\
\hline $\begin{array}{l}\text { Rhynchophorus } \\
\text { phoenicis }\end{array}$ & 1.57 & 1.63 & 7.47 & 6.23 \\
\hline
\end{tabular}

Figure.1 Photographs of the five edible insects

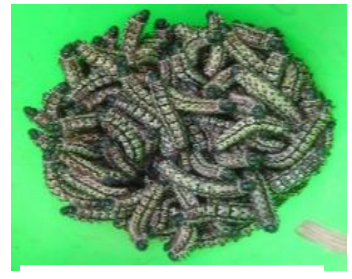

Imbrasia oyemensis

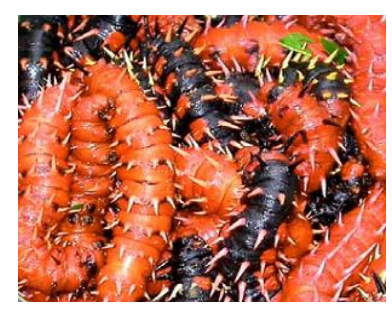

Bunaea alcinoe

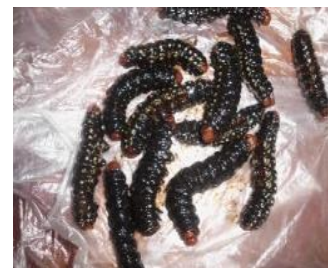

Imbrasia truncata

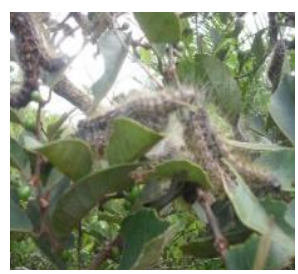

Imbrasia dione

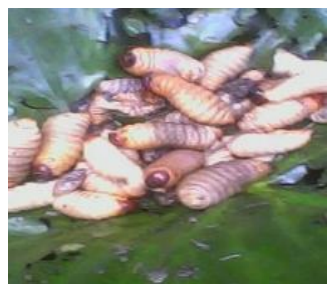

Rhynchophorus phoenicis 
The water contents (26-72.35\% EP) were lower than those reported by Womeni et al. 2009 for Imbrasia spp (75.56) and $R$. phoenicis (46.25 \% EP). The high water contents of these samples in the fresh state makes them difficult to be stored in this state, thus good conditions for storing are freezing or drying.

The high lipid content of $R$. Phoenicis (41.36\% EP) showed that this insect was rich in lipids, and this accounts for its palatability when fried or roasted as mentioned by Womeni et al. (2009). The lipid contents were higher than those of chicken (1.5), fish (2.75.0), and unprocessed milk (2.1-3.7), but similar to that of raw chicken egg $(9.5 \% \mathrm{EP})$, (Stadlmayr et al., 2012). When compared to beef or fish, these insects had high lipid contents and are therefore also good energy sources. Indeed, lipids are necessary in food because they increase palatability and retain the flavour of food (Aiyesanmi and Oguntokun, 1996). Womeni et al. (2009) showed that the larvae of $R$. phoenicis and Imbrasia spp were rich in Polyunsaturated Fatty Acids (PUFA), especially in linolenic and linoleic acids and contained some Saturated Fatty Acids (SFA), especially palmitic (Imbrasia spp), palmitoleic and stearic acids, with PUFA/SFA ratio of 16.70 in $R$. phoenicis and 1.01 in Imbrasia spp. PUFA/SFA ratios greater than 0.8 are associated to desirable levels of cholesterol and reduced risk of coronary heart diseases (Mann, 1993). The lipids in these insects could therefore help to enhance the flavour and palatability of foods, as well as playing a structural and functional role in the organism.

The protein contents of these insects (10$16.72 \% \mathrm{EP})$ were similar to that of raw chicken eggs (12.6g), but slightly lower than those of fresh fish (18-19) and fresh meat (18.4g/100g EP) which are known to be good protein sources (Stadlmayr et al., 2012). In Cameroon protein energy malnutrition affects mostly children under the age of five causing weight loss, wasting and stunted growth (EDS-MICS, 2011; Kana Sop et al., 2013). Given the high protein contents of these insects (especially the Lepidoptera with $16.72 \%$ protein), they could be ground into powder and mixed with carbohydrate-rich foods like pap, for children, in order to enhance the protein content of these meals.

The Lepidoptera (0.66-0.72\% EP) and the Coleoptera $(1.29 \%$ EP) had ash contents similar to those of fresh fish $(1-1.4 \%)$, raw fresh meat $(0.8-1.3 \%)$ and raw chicken $(0.8$ - 1\%) (Stadlmayr et al., 2012).

The chitin exoskeleton of these insects (especially the posterior and anterior portions of the larvae), or the tiny spikes they have on their skin in the grub stages (especially the Lepidoptera) contain fibres. The crude fibre contents of these insects $(3.31-5.6 \% \mathrm{EP})$ except I. dione $(2.1 \% \mathrm{EP})$ were higher than those found in some fruits (lemon, orange, mango, grape, ripe plantain), with fibre contents ranging from $1.2-2.3 \%$ edible portion. They were similar to those of vegetables like okra fruit, carrots and cassava leaves with $3.1-3.6 \%$ edible portion (Stadlmayr et al., 2012).

These insects were generally poor in carbohydrates (5-8.54\% EP). Most of the dishes consumed by the rural and some urban dwellers in Cameroon are rich in carbohydrates. Some of the carbohydratesrich staple foods include corn and its products, cassava and its products, cocoyams, plantains and potatoes. The low content of carbohydrates in these insects could be compensated by these commonly consumed carbohydrate rich dishes.

\section{Macrominerals}

These insects had higher calcium levels (2037.84) than unprocessed meat (5-15) and 
chicken (9mg), but similar values to those of some species of fish, Mackerel (20) and Tilapia $(28 \mathrm{mg} / 100 \mathrm{~g}$ EP). The phosphorus content of $R$. Phoenicis (180.43mg) was similar to that of beef (170-182mg), but lower than those of fish (210-281mg/100g EP) (Stadlmayr et al., 2012). Calcium and phosphorus are important minerals for bone formation. All the samples presented a ratio less than $1 / 2$, thus $\mathrm{Ca}$ will be rapidly absorbed in the gastrointestinal tract of children. The $\mathrm{Ca} / \mathrm{P}$ ratio influences the absorption peak of these minerals in the gastrointestinal tract. A ratio of $1 / 2$ for children and $1 / 1$ for adults presents a maximum absorption for this mineral in the respective individuals (O'dell, 1989; FAO/WHO, 2001).

The potassium contents of these insects (152$296 \mathrm{mg}$ ) were lower than those of meat (302$360 \mathrm{mg}$ ) and fish (333-499mg/100g EP) (Stadlmayr et al., 2012). These insects could only supply less than $10 \%$ of the AI (4.7g/day) for males, females and pregnant women of all age groups and less than $6 \%$ of the AI $(5.1 \mathrm{~g} / \mathrm{d})$ for lactating mothers of all age groups (FAO/WHO, 2001).

The magnesium contents (32-103.44) were higher than those of raw cow meat (22-25) and chicken (28mg/100g EP). The Mg levels in I. dione (32.13) and I. truncata (34.43) were similar to that of fish (33-36mg) while the other insects were about 2 to 4 times richer in $\mathrm{Mg}$ (49-103.44mg) than meat and chicken (Stadlmayr et al., 2012). These insects could therefore be considered as good sources of $\mathrm{Mg}$. Magnesium is indispensable in the metabolism of calcium. It is equally necessary for the proper functioning of the heart and it is a cofactor of many enzymes involved in energy production in the body (Chandra, 1990).

The sodium levels of the insects (0.38-1.68) were much lower than those of foods of animal origin which range from 50$2210 \mathrm{mg} / 100 \mathrm{~g}$ EP (Stadlmayr et al., 2012). Only $R$. phoenicis had a sodium content greater than $1 \mathrm{mg} / 100 \mathrm{~g}$ EP. FAO/WHO (2001) recommends a reduction in sodium intake to < $2 \mathrm{~g}$ of salt/day in order to regulate blood pressure and reduce the risk of stroke and coronary heart disease in adults. All these insects contained very low levels of sodium, far less than $2 \mathrm{~g} / 100 \mathrm{~g} \mathrm{EP}$, hence could be good for individuals with high blood pressure and coronary heart disease.

In general, the Coleoptera (R. phoenicis) had the highest levels of all the macromineralsanalysed, which are important for bone and teeth formation (especially $\mathrm{Ca}$ and $\mathrm{P}$ ) in children. The $\mathrm{Ca} / \mathrm{P}$ ratio was less than $1 / 2$, indicating a good $\mathrm{Ca}$ absorption. $R$. phoenicis may be recommended for children with rickets and for the old persons, to prevent osteoporosis. The $\mathrm{Na}$ levels were generally low $(0.38-1.68 \mathrm{mg})$ and were in accordance with WHO recommendations for salt intake $(<2 \mathrm{~g}$ of salt/day), hence, these insects could help to prevent high blood pressure. They also had high magnesium levels, which is necessary for calcium metabolism and for the proper functioning of the heart.

\section{Microminerals}

The copper contents of these samples $(0.26$ 1.57) are higher than those of other food sources of animal origin like raw lean meat (0.09) and raw Mackerel (0.06 mg/100g EP) (Stadlmayr et al., 2012). A portion of $100 \mathrm{~g}$ of these samples could meet up with the Recommended Dietary Allowances of $\mathrm{Cu}$ (RDA; 0.26-0.985mg/day) for all age groups of individuals (FAO/WHO, 2001). This indicates that these samples could be used as sources of copper. Copper is indispensable for the transport of iron in the organism, and it is a cofactor with manganese of superoxide 
dismutase, an enzyme which fights against oxidative stress (Chandra, 1990).

Food is considered to be rich in manganese when it contains more than $5 \mathrm{mg}$ of $\mathrm{Mn} / 100 \mathrm{~g}$ of food (FAO, 1970). Only I. dione with a Mn content of $8.32 \mathrm{mg} / 100 \mathrm{~g}$ EP was rich in $\mathrm{Mn}$. However, $100 \mathrm{~g}$ of EP of $R$. phoenicis (1.63mg), I. oyemensis (1.66mg) and I. dione (8.32mg) contain sufficient $\mathrm{Mn}$ to meet up with the AI (1.2-2.6mg/day) of healthy individuals aged 9 and above (FAO/WHO, 2001). Manganese is a trace element involved in bone formation, proper functioning of the immune system and in association with vitamin $\mathrm{K}$, favours blood clotting (Aschner and Aschner, 2005).

Their iron values $(1.12-7.47 \mathrm{mg})$ are similar to those of Tilapia $(1.2 \mathrm{mg})$ and raw lean beef (2.1mg) except $I$. truncata $(1.14 \mathrm{mg})$ and $I$. dione $(1.12 \mathrm{mg})$ with lower values but higher than that of Mackerel $(0.8 \mathrm{mg} / 100 \mathrm{~g}$ EP) (Stadlmayr et al., 2012). Food is said to be rich in iron when it contains $16 \mathrm{mg}$ of iron per $100 \mathrm{~g}$ EP of food (FAO/WHO, 2001), hence none of these insects was rich in iron. However, these insects had some amount of iron, which could be used to supplement iron intakes of children, pregnant and lactating women and women at the age of procreation who are predisposed to iron deficiency anaemia as a means of contributing to the fight against iron deficiency in Cameroon (EDS-MICS, 2011).

These insects had higher $\mathrm{Zn}$ levels than some foods of animal origin such as chicken $(0.84 \mathrm{mg})$, fish $(0.49-1.57 \mathrm{mg})$ but similar to that of beef (3.4-3.6mg/100g EP) (Stadlmayr et al., 2012). The Adequate Intake of $\mathrm{Zn}$ for infants is $2 \mathrm{mg}$ /day and the Recommended Daily Allowance for children aged 1-6 is 3$5 \mathrm{mg} /$ day (FAO/WHO, 2001). 100g EP of these insects can supply sufficient $\mathrm{Zn}$ for infants while $I$. dione $(4.55 \mathrm{mg})$ and $R$. phoenicis $(6.23 \mathrm{mg}$ ) can supply enough $\mathrm{Zn}$ for 1-6 year old children.

In general, these insects were rich in microminerals especially, copper and zinc. The $\mathrm{Cu}$ levels in these insects could meet up with the RDA for $\mathrm{Cu}$ in all age groups of individuals. The $\mathrm{Zn}$ levels could supply sufficient $\mathrm{Zn}$ for infants, while $I$. dione and $R$. phoenicis could supply enough $\mathrm{Zn}$ for 1-6 year old children. I. dione contained sufficient Mn to meet up with the AI of healthy individuals aged 9 and above.

In conclusion, this work which was aimed at determining the nutritive value (macronutrients and minerals) of 5 Cameroonian edible insects from 2 orders, Lepidoptera (I. dione, I. truncata, I. oyemensis and B. alcinoe) and Coleoptera $(R$. phoenicis) revealed that they had good levels of macronutrients, with $R$. Phoenicis (Coloeptera) showing the highest levels of all the macronutrients. These insects had high contents of proteins and lipids, hence could be used as potential food complements to contribute to the fight against protein-calorie malnutrition. They also had good crude fibre levels that could help to prevent constipation, colon cancer and coronary heart disease. The insects had good levels of minerals. $R$. phoenicis (Coleoptera) also had the highest levels of all the minerals analysed, except $\mathrm{Mn}$ whose level was highest in $I$. dione. The $\mathrm{Ca} / \mathrm{P}$ ratio was less than $1 / 2$, indicating good $\mathrm{Ca}$ absorption. The $\mathrm{Mg}$ levels of the insects were high enough to supply sufficient $\mathrm{Mg}$ for $1-8$ year old children, needed for proper functioning of the heart and some enzymes, acting as cofactors. The $\mathrm{Na}$ levels were generally low ( $<2 \mathrm{~g}$ of salt/day), which could help to prevent high blood pressure. All the insect samples were very rich in the microminerals, $\mathrm{Cu}$ and $\mathrm{Zn}$. The $\mathrm{Cu}$ levels in these insects could meet up with the RDA for $\mathrm{Cu}$ in all age groups of individuals. The $\mathrm{Zn}$ 
levels could supply sufficient $\mathrm{Zn}$ for infants while $I$. dione and $R$. phoenicis could supply enough $\mathrm{Zn}$ for 1-6 year old children. I. dione contained sufficient $\mathrm{Mn}$ to meet up with the AI of healthy individuals aged 9 and above. These insects could therefore serve as potential sources of proteins, lipids and fibres, $\mathrm{Ca}, \mathrm{P}, \mathrm{Mg}, \mathrm{Cu}$ and $\mathrm{Zn}$ (especially $R$. phoenicis) and $\mathrm{Mn}$ (especially I. dione) to help balance the staple carbohydrate-rich foods prevent overcome and some mineral deficiencies

\section{References}

Aschner J. L. and Aschner M. (2005). Nutritional aspects of manganese homeostasis. Molecular Aspects of Medicine, 26: 353-362.

Association of Official Analytical Chemists (AOAC). 1980. Official Methods of Analysis. (13th ed.). William Horwitz, Washington, D.C. Association of Official Analytical Chemists.

Aiyesanmi A. F. and Oguntokun M.O., 1996. Nutrient composition of Dioclea reflexa seed: An underutilised edible legume. Rivista Italiana Delle Sostanze Grasse, 73 (11): 521 - 523.

Benton J.J. and Vernon W.C., 1990. Sampling, handling and analyzing plant tissue samples. In R. L. Westerman (ED) soil testing and plant analysis (3rd ed). SSSA Book Series 3, 784p.

Chandra, 1990. Micro- nutrients and immune functions: An overview. Annual New York Academy of Sciences.587:9-16.

Durst P.B. and Shono K., 2010. Edible forest insects: Exploring new horizons and traditional practices. Proceedings of a Workshop on Asia-Pacific Resources and their Potential for Development, 19-21. February 2008, Chaiang Mai, Thailand. Bangkok: Food and Agricultural Organisation of the United Nations: 1-4.
Enquête Démographique et de Santé et à Indicateurs Multiples, 2011. Rapport Préliminaire, Institut National de la Statistique. République du Cameroun, 44pp.

Food and Agriculture Organization. 1970. Table de composition des aliments à l'usage de l'Afrique. Documents Nutrition. Rome, 3: pp 4 - 136.

Food and Agriculture Organization / World Health Organization. 2001. Human vitamin and mineral requirements. Report of a joint FAO/WHO expert consultation Bangkok, Thailand, 281p.

Kana Sop M.M., Djeukeu A.W., Gouado I., Nolla N.P., Mananga M.J., Amvam Z.P. and Ekoe T. 2013. Feeding Practices and Nutritional Parameters of Children Aged 6-14 years. Global Journal of Medical Research Inter Disciplinary, 13 (2): 1-9.

Mann J., 1993. Diseases of the heart and circulation: the role of dietary factors in aetiology and management. In: Garrow J. W., James, eds. Human Nutrition and Dietetics. London: Churchill, Livingstone: pp 619-50.

Muafor F.J., Levang P., Angwafo T.E. and Le Gall P., 2012. Making a living with forest insects: beetles as an income source Southwest Cameroon. International Forestry Review.14 (3), Vol.14 (3): 314-325.

Muafor F.J., Levang P. and Le Gall P., 2014. A crispy delicacy: Augosoma beetle as alternative source of protein in East Cameroon. International Journal of Biodiversity, Volume 2014), Article ID 214071, 7 pages.

Muafor F.J., Gnetegha A.A., Le Gall P. and Levang P., 2015. Exploitation, trade and farming of palm weevil grubs in Cameroon. Working Paper 178. Bogor, Indonesia: Center for International Forestry Research. Page 5 . 
Murphy J. and Riley J.P., 1962. A modified single solution method for determination of phosphate in natural waters. Analytica Chimica Acta, 27: 31-36.

O'dell B.L., 1989. Mineral interactions relevant to nutrient requirements. Journal of Nutrition, 119: 1832-1838.

Pongou R., Ezzati M. and Salomon J.A., 2006. Household and community socioeconomic and environmental determinants of child nutritional status in Cameroon: BioMed Central Public Health; 6: 98. doi: 10.1186/14712458-6-98.

Stadlmayr B., Charrondiere R.U., Enujiugha N.V., Bayili G.R., Fagbohoun G.E., Samb B., Addy P., Barikmo I., Ouattara F., Oshaug A., Akinyele I., Amponsah A.G., Bomfeh K., EneObong H., Ifeyironwa F.S., Thiam I., and Burlingame B., 2012. West African Food Composition Table. Publisher: Vialle delle Terme di
Caracalla, 00153 Rome, Italy: p 5775.

World Health Organization. Global data base on child growth and malnutrition. WHO; 2012.

Womeni H.M., Linder M., Tiencheu B., Mbiapo F., Villeneuve P., Fanni J. and Parmentier M., 2009. Oils of insects and larvae consumed in Africa: potential sources of polyunsaturated fatty acids. $O C L$ - Oléagineux, Corps Gras, Lipides, 16 (4): 230-235.

Womeni H. M., Tiencheu B., Linder M., Chouatcho Nabayo E. M., Tenyang N., Tchouanguep Mbiapo F., Villeneuve P., Fanni J. and Parmentier M., 2012. Nutritional value and effect of cooking, drying and storage process on some functional properties of Rhynchophorus phoenicis. International Journal of Life Science and Research, 2 (3): 203-219.

\section{How to cite this article:}

Achu Mercy B. Loh, K.B. Yisa Njowe and Kana Sop, M.M. 2017. Preliminary Proximate Composition and Mineral contents of Five Edible Insects from Cameroon. Int.J.Curr.Microbiol.App.Sci. 6(3): 1984-1995. doi: https://doi.org/10.20546/ijcmas.2017.603.226 